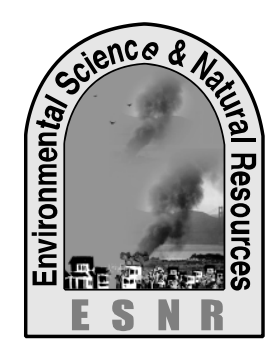

\title{
Assessing the Adequacy, Utilization and Repayment of Grameen Bank Income Generating Loans on Rural Women in Selected Areas of Tangail District
}

\author{
S. A. Labani ${ }^{1^{*}}$, M. Z. Islam ${ }^{2}$ and A. S. M. G. Hafeez ${ }^{1}$ \\ ${ }^{1}$ Department of Agricultural Finance, ${ }^{2}$ Department of Entomology \\ Bangladesh Agricultural University, Mymensingh-2202 \\ *Corresponding author: sharminalabani@gmail.com
}

\begin{abstract}
A study was conducted to assess the adequacy, utilization and repayment of Grameen Bank (GB) income generating loans on rural women in selected areas of Tangail district. The study was conducted with socio-economic characteristics of the women borrowers, assessing the adequacy, utilization and repayment of loan. With this end in view, 60 respondents were purposively selected from three villages namely Hemnagar, Volapara and Shimlapara of which 10 were engaged in farming, 21 were engaged in livestock rearing, 19 were engaged in petty business, 5 were engaged in tailoring and 5 were indirectly engaged in van/rickshaw pulling. Tabular and statistical analyses were applied for achieving the objectives. In the study area, higher proportions (55 per cent) of women were middle aged and 93 percent were married. About 75 percent had signature ability, 18 and 7 per cent studied up to primary and secondary level respectively. Average family size of the respondents was5.36; average annual income and saving of the respondents were Tk. 65958.05 and 8769.65 respectively. Six explanatory variables i.e. Age, education, family size, occupation, income and expenditure were considered for repayment of loan in empirical model. Age, family size, income and expenditure had significant impact on repayment of loan. Average amount of credit received by the respondents was Tk. 8139 and on an average 82 percent of the loaned money was utilized for the reported IGAs. Due to poor economic condition, the respondents could not utilize the total loaned money in productive purposes. Overall loan recovery percentage was found to be quite satisfactory. They repaid their loan on time with the hope of getting more credit in future and because of regular supervision by the bank's field level workers and pressure of the group leaders.
\end{abstract}

Key words: Adequacy, Loan repayment, Utilization

\section{Introduction}

Adequacy, utilization and repayment of loan are very important factors for both lenders and receivers of credit. Adequacy of loan shows the sufficiency of fund which makes borrowers anxious free to invest in productive activities. Proper use of loan promotes increased production and benefits the borrowers involved. If the borrowed funds are employed in unproductive purposes like marriage ceremony, pleasure trip etc. or speculative purposes, the repayment in the normal course will become uncertain. The repayment of credit shows that the borrowers utilized credit properly and earn profit from their investment. The study examines the adequacy of credit and its utilization and loan repayment by the borrowers. Bangladesh Bank (1992) found that about 57 per cent of the members possessed less than 0.6 ha of land (including homestead) and noticeable change was occurred after forming the group of Grameen Bank (GB). The extent of petty business has increased from 20 to 44 percent and animal and poultry rearing rose from 14 to 27 per cent. Selling daily physical labor decreased from 14 to 3 percent and participation in agricultural activities decreased from 14 to 11 percent. It was observed that the group members were more interested in cottage industries compared to other activities. Gibbons (1994) pointed out increasing proof that the GB financial system had general applicability among the very poor all over the world. He showed that different nations from Asia, Africa, and North America attained satisfactory loan repayment record of 99 to 100 percent following the GB model. Begum and Chakrabortty (1995) undertook a research to examine the relationship between the rural poor women and the GB. The findings revealed that women who made effective economic contribution towards running their families enjoyed relatively greater acceptability in their families' decision-making, either independently or jointly with their husbands than women who could not make effective contribution towards running their families. It may therefore, be understood that by facilitating women's' participation in income share of the GB had played a positive and significant role in improving their status in general and that of their position within the family's decision making in particular. Again as far as family saving was concerned, women having loan would have greater influence than non-loanee women. Khan (1995) in a study entitled "The Effects of Wage Employment and Credit on Women in Bangladesh" found that in many cases women participated in decision-making process about the use of their loan exerted control over their wage and income and spent it on household welfare. Kabir and Amin (1995) conducted a study on the impact of rural women's participation in village based development programmes with three development institutions BRAC, BRDB and the GB. The study showed that participation of rural women in IGAs had increased the use of contraceptives and improved their ability in decisionmaking. Sharma and Zeller (1997) studied repayment performance in group-based credit programmes of ASA, BRAC and RDRS in Bangladesh. The study concluded that if the basic principles of prudential banking were adhered to, repayment rates could be good even in poor and remote communities. The important thing for financial institutions was to render service so that it became worthwhile for the poor to establish a profitable long term association. Chowdhury et al. (1998) examined the loan utilization behavior of a sample of 109 GB women borrowers and explored the relationships between the individual socio-economic characteristics of the women and loan utilization. He found that loans were granted for agricultural purposes. A loan utilization index was computed determining 
utilization score. A considerable proportion (80 per cent) of borrowers had high loan utilization scores. Younger borrower women and those with small families showed the highest loan utilization.

\section{Materials and Methods}

To attain the objectives of the study, three villages namely Hemnagar, Bholapara and Shimlapara under Gopalpurupazila of Tangail district were purposively selected. The selected villages were under the functional jurisdiction of the GB Hemnagar branch. Data were collected by the researcher herself through personal interview with the selected women. Data were collected during the period from March to May, 2008. In order to collect relevant information, the selected rural women were interviewed by the researcher herself. Before taking interview, the whole academic purpose of the study was clearly explained and made clear to the sample respondents and they were assured that the study was purely an academic one and was not likely to have any adverse effect on them. At the time of interview, the researcher asked questions systematically and explained wherever felt necessary. To overcome errors and to ensure collection of accurate data from the field, all possible efforts were made by the researcher. After accomplishment of interview, the interview schedules were checked to verify the accuracy of information. The questionnaires containing incomplete and doubtful information were recollected during the period of data collection. Thus, information obtained for the present study was fairly reliable.) The collected data were manually edited and coded. Then all the collected data were summarized and scrutinized carefully. Data were processed to transfer to master sheets to facilitate tabulation in order to meet the objectives of the study. Moreover data entry was made in computer and analysis was done using the concerned Microsoft Excel and Statistical Package for Social Science (SPSS).It may be noted that information were collected initially in local units. After necessary checking they were converted into standard international units. In this study tabular and statistical analyses were used to achieve the set objectives. In tabular analysis qualitative data were converted into quantitative data by using suitable scoring. Regression analysis was used in the study to evaluate repayment performance of the respondents.

\section{Results and Discussion}

\section{Credit received and adequacy of loan}

Capital is required for investing in IGAs. To meet this capital requirement credit is helpful as it creates scope for further investment. Findings regarding the average amount of credit received and its adequacy in 2007 have been presented in tables 1 and 2.The overall average amount of credit received by the respondents in the study area was Tk.8139.40. Table 1, shows the average amount of credit received by the livestock bearers was found maximum (Tk.10416.00) while minimum amount was received by the tailors (Tk.7200.00).

Table 1. Average amount of credit received by the borrowers

\begin{tabular}{|l|c|c|}
\hline Loan category & $\begin{array}{l}\text { No. of } \\
\text { respondents }\end{array}$ & $\begin{array}{l}\text { Average amount } \\
\text { (Tk.) }\end{array}$ \\
\hline Farming & 10 & 7276.00 \\
\hline $\begin{array}{l}\text { Livestock } \\
\text { rearing }\end{array}$ & 21 & 10416.00 \\
\hline Petty business & 19 & 8305.00 \\
\hline Tailoring & 5 & 7200.00 \\
\hline $\begin{array}{l}\text { Van/rickshaw } \\
\text { pulling }\end{array}$ & 5 & 7500.00 \\
\hline Total & 60 & 8139.40 \\
\hline
\end{tabular}

Table 2, shows that 90 percent of the respondents said that they got adequate amount of credit from GB and only 10 percent said that the loan received from GB was not adequate.

Table 2. Adequacy of loan received from GB in 2007

\begin{tabular}{|l|c|c|}
\hline $\begin{array}{l}\text { Loan } \\
\text { adequacy }\end{array}$ & $\begin{array}{l}\text { Frequency } \\
\text { (No.) }\end{array}$ & Percent (\%) \\
\hline No & 6 & 10.00 \\
\hline Yes & 54 & 90.00 \\
\hline Total & 60 & 100.00 \\
\hline
\end{tabular}

\section{Utilization of loan}

Table 3. Average amount of loan utilized for different purposes

\begin{tabular}{|c|c|c|c|c|c|}
\hline Loan category & $\begin{array}{c}\text { Concerned } \\
\text { IGA(Tk) }\end{array}$ & $\begin{array}{c}\text { Household food } \\
\text { consumption(Tk) }\end{array}$ & $\begin{array}{c}\text { Household } \\
\text { non-food } \\
\text { consumption(Tk) }\end{array}$ & $\begin{array}{c}\text { Repayment of } \\
\text { old debt(Tk) }\end{array}$ & $\begin{array}{c}\text { All purposes } \\
\text { (Tk) }\end{array}$ \\
\hline Farming & 5610.00 & - & 1666.00 & - & 7276.00 \\
\hline Livestock rearing & 8166.00 & 750.00 & - & 1500.00 & 10416.00 \\
\hline Petty business & 6805.00 & - & - & 1500.00 & 8305.00 \\
\hline Tailoring & 6200.00 & 500.00 & - & 500.00 & 7200.00 \\
\hline $\begin{array}{c}\text { Van/rickshaw } \\
\text { pulling }\end{array}$ & 6500.00 & - & 1000.00 & & 7500.00 \\
\hline All & 6656.20 & 250.00 & 533.20 & 700.00 & 8139.40 \\
\hline
\end{tabular}

Proper utilization of credit is a prerequisite to attain aims and targets of both credit disbursement and credit receipt as well as for growth of income. In this subsection, a thorough investigation has been made to see the pattern of loan utilization in which sampled borrowers spent their loaned money received from the
GB during the year under study. Table 3 shows the average amount of loan received and average amount of loan utilized for concerned IGAs and also shows the amount of loaned money used for other purposes. Table 3 , reveals that borrowers on an average received $\mathrm{Tk}$. 8139.40 for investing in different IGAs but they 
actually utilized on an average Tk. 6656.20 for IGAs and they spent on an average Tk. 250.00, 533.20 and 700.00 for household food consumption, household

\section{Loan repayment}

Loan received from the GB is to be repaid along with interest in 44 weekly installments and in each installment a borrower had to repay Tk. 25 for each Tk. 1000 of which Tk. 22 for capital and Tk. 3 for interest starting from the next week of receiving loan in hand. Repayment is made to the bank staff at the next centre meeting on definite time. Table 4shows the average repayment of loan by the borrowers. Table 4reveals that the average amount of loan repaid was found to be Tk. $8236.43,11790.91,9401.26,8150.40$ and 8490.00 for nonfood consumption and repayment of old debt respectively.

farming, livestock rearing, petty business, tailoring and van/rickshaw pulling respectively. Overall loan recovery percentage observed during the study period was found quite satisfactory. Hope of getting more credit in future had been reported by most of the borrowers as the major factor of timely loan repayment. Regular supervision by the bank's field level workers and pressure of group leader and other members of the group also had been reported by some of the borrowers as important factors of timely loan repayment.

Table 4. Amount of principal and interest paid by the respondents

\begin{tabular}{|c|c|c|c|c|c|}
\hline \multirow[b]{2}{*}{ Loan category } & \multicolumn{4}{|c|}{ Average amount paid } & \multirow[b]{2}{*}{$\%$ of total repayment } \\
\hline & $\begin{array}{c}\text { Installment } \\
\text { (No.) }\end{array}$ & $\begin{array}{l}\text { Principal } \\
\text { (Tk.) }\end{array}$ & $\begin{array}{l}\text { Interest } \\
\text { (Tk.) }\end{array}$ & $\begin{array}{l}\text { Total } \\
\text { (Tk.) }\end{array}$ & \\
\hline Farming & 44 & 7276.00 & 960.43 & 8236.43 & 100 \\
\hline Livestock rearing & 44 & 10416.00 & 1374.91 & 11790.91 & 100 \\
\hline Petty business & 44 & 8305.00 & 1096.26 & 9401.26 & 100 \\
\hline Tailoring & 44 & 7200.00 & 950.40 & 8150.40 & 100 \\
\hline Van/rickshaw pulling & 44 & 7500.00 & 990.00 & 8490.00 & 100 \\
\hline Total & 44 & 8139.40 & 1074.40 & 9213.80 & 100 \\
\hline
\end{tabular}

\section{Regression analysis}

The empirical model was specified as: $Y=A X_{1}^{b_{1}} X_{2}^{b_{2}} X_{3}^{b_{3}} X_{4}^{b_{4}} X_{5}^{b_{5}} X_{6}{ }^{b_{6}} e^{u}$

The equation may alternatively be expressed log-linearly as:

$\ln \mathrm{Y}=\ln \mathrm{a}+\mathrm{b}_{1} \ln \mathrm{X}_{1 \mathrm{i}}+\mathrm{b}_{2} \ln \mathrm{X}_{2 \mathrm{i}}+\mathrm{b}_{3} \ln \mathrm{X}_{3 \mathrm{i}}+\mathrm{b}_{4} \ln \mathrm{X}_{4 \mathrm{i}}+\mathrm{b}_{5} \ln \mathrm{X}_{5 \mathrm{i}}+\mathrm{b}_{6} \ln \mathrm{X}_{6 \mathrm{i}}+\mathrm{e}^{\mathrm{u}}$.

Where,

$\mathrm{Y}=$ Amount of loan repaid by the loaner (Tk.),

$\mathrm{a}=$ Constant term,

$\mathrm{X}_{1}=$ Age of the respondents (years),

$\mathrm{X}_{2}=$ Education (years of schooling),

$\mathrm{X}_{3}=$ Family size (number),

$\mathrm{X}_{4}=$ Occupation $(1,2,3,4,5)$,

$\mathrm{X}_{5}=$ Income $(\mathrm{Tk}$.$) ,$

$\mathrm{X}_{6}=$ Expenditure (Tk.),

$\mathrm{e}^{\mathrm{u}}=$ Error term;

$\mathrm{b}_{1}, \mathrm{~b}_{2}, \ldots \ldots, \mathrm{b}_{6}=$ Co-efficient of respective variables

Table 5 reveals that amulticolinearity test was conducted to examine the existence of high degree of association among the variables and the test indicated that multicolinearity among the variables did not exist. Age of the respondents $\left(\mathrm{X}_{1}\right)$ : Regression co-efficient of the respondents' age was found to be negative $\left(b_{1}=-\right.$ 0.045) which is significant at 10 percent level of confidence. It indicates that repayment of loan is negatively and significantly affected by age of the respondents. Because aged person's earning ability is relatively low hence low repayment of loan. Education $\left(\mathrm{X}_{2}\right)$ : Regression co-efficient of educational qualification of the respondents was 0.031 being statistically insignificant however had positive sign. It means no significant effect by the variable. Family size $\left(\mathrm{X}_{3}\right)$ : The co-efficient of the variable family size was found to be negative $\left(b_{3}=-0.065\right)$ and significant at $5 \%$ level. It indicates that repayment of loan tends to decrease with increase in respondents family size. Expected association was there with loan repayment

behavior. Occupation $\left(\mathrm{X}_{4}\right)$ : Regression co-efficient of the respondents' occupation was 0.034 which is statistically insignificant. Income $\left(\mathrm{X}_{5}\right)$ : Regression coefficient of the respondents' income was 5.182 which are significant at $1 \%$ level. It indicates that keeping other variables constant, 1 percent increase in income would lead to an increase in repayment of loan by 5.182 percent. Expenditure $\left(\mathrm{X}_{6}\right)$ : The co-efficient of the variable expenditure of the respondents was also negative but significant at $1 \%$ level, which indicates that keeping other variables constant, 1 percent increase in expenditure, would lead to a decrease in repayment performance by 4.895 percent. Value of $\mathrm{R}^{2}$ and adjusted $\mathrm{R}^{2}$ : The value of the co-efficient of multiple determinations $\mathrm{R}^{2}$ was 0.875 which means that the explanatory variables included in the model explained 87.5 percent of the variation in loan repayment performance of the respondents. It is also evident from the same table that the value of adjusted $R^{2}$ is 0.850 indicating that after taking into account the degrees of 
freedom the explanatory variables in the model explained 85 percent of the variations in the dependent variable.

Table 5. Estimated values of regression co-efficient

\begin{tabular}{|c|c|c|c|c|}
\hline Explanatory variables & $\begin{array}{c}\text { Estimated values of } \\
\text { regression co-efficient }\end{array}$ & t-values & Significant level & Standard error \\
\hline Constant & -1.40 & -0.783 & 0.543 & 1.725 \\
\hline Age $\left(\mathrm{X}_{1}\right)$ & $-0.045^{*}$ & -0.401 & 0.100 & -0.591 \\
\hline Education $\left(\mathrm{X}_{2}\right)$ & 0.031 & 0.047 & 0.510 & 0.663 \\
\hline Family size $\left(\mathrm{X}_{3}\right)$ & $-0.065^{* *}$ & -2.915 & 0.023 & 0.356 \\
\hline Occupation $\left(\mathrm{X}_{4}\right)$ & 0.034 & 0.482 & 0.636 & 0.034 \\
\hline Income $\left(\mathrm{X}_{5}\right)$ & $5.182^{* * *}$ & 11.214 & 0.000 & -1.907 \\
\hline Expenditure $\left(\mathrm{X}_{6}\right)$ & $-4.895^{* * *}$ & -9.583 & 0.000 & - \\
\hline $\mathrm{R}^{2}$ & 0.875 & - & - & - \\
\hline Adjusted $\mathrm{R}^{2}$ & 0.850 & - & - & - \\
\hline F-value & 53.761 & - & - & \\
\hline
\end{tabular}

* significant at 10 percent level; ** significant at 5 percent level; *** significant at 1 percent level

\section{Conclusions}

Based on the findings of the study the following conclusion may be drawn: 1) Women might be good associates of the socio-economic development of the family as well as of the country. 2) It was found that all women borrowers under study were all along regular in repaying their installments. 3) Women members were given preference in decision making of family affairs. 4) Provision of credit is an important element for getting the rural women involved in income generating and development activities.

\section{References}

Bangladesh Bank, 1992. An Evaluation of Grameen Bank Project: An Experiment Among the Landless Poor in Rural Bangladesh, Vol.48:1(2).12391297 Bangladesh Bank, Dhaka.

Begum, A. and Chakrabortty, K. 1995. "Economic Contribution of Rural Women and their Participation in the Household Decision Making Process in Bangladesh", Research Note, The Bangladesh Journal of Agricultural Economics, 18:1. 51-59.

Chowdhury, S. H.; Kashe, M. A. and Miah, A. M. 1998. Loan Utilization Behavior of the Women Beneficiaries of Grameen Bank: An Empirical Study in Bangladesh Economic-Affairs; Calcutta, 43:3, 160-167.

\section{Acknowledgements}

The authors acknowledge all of the teachers and staffs of the Department of Agricultural Finance, Bangladesh Agricultural University, Mymensingh, Bangladesh for their kind cooperation and supports during the study period. The authoress extends her grateful thanks to the Manager and all staffs of the Grameen Bank Hemnagar Brach for supplying necessary information. Special thanks and appreciation are also due to the respondents of the study areas who supplied relevant data for preparing the study.

Gibbons, D. S. 1994 "Introduction", The Grameen Reader (GR), Vol.10:3. 19-23 Grameen Bank, Mirpur-2, Dhaka.

Kabir, M. and Amin, R. 1995. The Impact of Poor Woman's Participation in Village based Development Programme on Fertility, The Journal of Rural Development, 25(1): 25-45.

Khan, M. R. 1995. "The Effect of Wage Employment and Credit for Women in Bangladesh", 12:5, 230255.

Sharma, M. and Zeller, M. 1997. Repayment Performance in Group Based Credit Programmes in Bangladesh: International Food Policy Research Institute. Washington D.C., USA, 10, 1731-1742; 31. 